\title{
UPAYA PEMANFAATAN LINGKUNGAN SEKITAR SEBAGAI SUMBER BELAJAR ANAK
}

\section{Moh. Miftahul Choiri}

Universitas Nahdlatul Ulama Sunan Giri Bojonegoro

\section{Info Artikel}

Sejarah Artikel:

Diterima 18 Okt 2017

Disetujui 18 Nov 2017

Dipublikasikan Des 2017

Keywords: Community Environment, Learning Resources, Children

\begin{abstract}
This article seeks to examine the child's learning environment. In education is better known as Tri Education Center. Namely three educational environments that can support the learning process of children. The three environments are the family environment, school environment and the environment (community). In the context of education, society is the third environment after family and school. In this article the authors would like to invite a look back that the community environment has an important influence on the learning process of children. Because most of the time the child is in the family and society. For it becomes a necessity of the community participate in education either directly or indirectly. Because the community is a maid in the process of maturation of individuals as members of groups in a society. The learning process in society is not limited by time and space. As long as the children interact and socialize with the environment it can be said that as their learning process. Through this library research hope can determine how far the role of the community environment in helping children's learning process.
\end{abstract}

\begin{abstract}
Abstrak
Artikel ini berupaya mengkaji tentang lingkungan belajar anak. Dalam dunia pendidikan lebih dikenal dengan istilah Tri Pusat Pendidikan. Yaitu tiga lingkungan pendidikan yang dapat menunjang proses belajar anak. Ketiga lingkungan tersebut adalah lingkungan keluarga, lingkungan sekolah dan lingkungan sekitar (masyarakat). Dalam konteks pendidikan, masyarakat merupakan lingkungan ketiga setelah keluarga dan sekolah. Pada artikel ini penulis ingin mengajak melihat kembali bahwa lingkungan masyarakat mempunyai pengaruh penting terhadap proses belajar anak. Karena sebagian besar waktu anak berada dalam lingkup keluarga dan masyarakat. Untuk itu menjadi sebuah keniscayaan masyarakat ikut berpartisipasi dalam pendidikan baik secara langsung maupun tidak langsung. Karena masyarakat merupakan pembantu pada proses pematangan individu sebagai anggota kelompok dalam suatu masyarakat. Proses pembelajaran dalam masyarakat tidak dibatasi oleh ruang dan waktu. Selama anak berinteraksi dan bersosialisasi dengan lingkungan maka bisa dikatakan itu sebagai proses belajar mereka. Melalui penelitian kepustakaan ini harapannya dapat menentukan seberapa jauh peran lingkungan masyarakat dalam membantu proses belajar anak.
\end{abstract}

(C) 2017 Universitas Muria Kudus
Program Studi Pendidikan Guru Sekolah Dasar

Fakultas Keguruan dan Ilmu Pendidikan Universitas Muria Kudus

Kampus UMK Gondangmanis, Bae Kudus Gd. L. 1t I PO. BOX 53

Kudus

Tlp (0291) 438229 ex.147 Fax. (0291) 437198

E-mail: choirinafik90@gmail.com
p-ISSN 2087-9385

e-ISSN 2528-696X 


\section{PENDAHULUAN}

Dalam dunia pendidikan kita mengenal istilah Tri Pusat Pendidikan. Tiga lingkungan yang menjadi faktor pendukung proses belajar anak. Ki Hajar Dewantoro (2013) berpendapat bahwa ada tiga lingkungan pendidikan yang dikenal dengan tri pusat pendidikan yaitu lingkungan keluarga, sekolah dan masyarakat. Ketiga lingkungan ini saling berkaitan dalam proses membantu tercapainya tujuan belajar anak.

Apakah salah satu lingkungan tertentu mempunyai peran yang lebih besar dari yang lain. Untuk menjawabnya memerlukan sebuah kajian dan penelitian. Dalam artikel ini akan dibahas lebih khusus tentang lingkungan sekitar (masyarakat) dalam membantu proses belajar anak. Serta seberapa besar peran masyarakat sebagai penunjang proses belajar anak.

Barnadib (1971) menyatakan bahwa masyarakat sebagai kumpulan orang yang menempati daerah, diikat oleh pengalamanpengalaman yang sama, memiliki sejumlah penyesuaian dan sadar akan kesatuannya, serta dapat bertindak bersama untuk mencukupi krisis kehidupannya. Antar satu daerah dengan daerah yang lain mempunyai perbedaan suku bangsa, bahasa, adat istiadat dan kebudayaan. Bahkan dalam satu daerah saja mereka mempunyai kebiasaan yang berbeda beda. Dengan perbedaan seperti itu sesungguhnya menambah khasanah kebangsaan sebagai warga negara.

Purwanto (1994: 59) menyatakan pada dasarnya lingkungan masyarakat mencakup beberapa aspek diantaranya: pertama, Tempat (lingkungan fisik) keadaan iklim, tanah. Kedua, Kebudayaan (lingkungan budaya). Ketiga, kelompok hidup masyarakat (lingkungan sosial atau masyarakat).

Dalam konteks pendidikan, masyarakat merupakan lingkungan ketiga setelah keluarga dan sekolah. Lingkungan masyarakat mempunyai peran penting dalam menunjang proses belajar anak. Syam (1984) menyatakan bahwa hubungan masyarakat dengan pendidikan sangat bersifat korelatif, bahkan seperti telur dengan ayam. Masyarakat maju karena pendidikan dan pendidikan yang maju hanya ditemukan dalam masyarakat yang maju pula. Untuk itu sebagai warga masyarakat kita ciptakan suasana belajar yang kondusif. Agar dapat mendukung proses belajar anak.

Sebutan masyarakat yang maju ialah masyarakat madani. Masyarakat tersebut dapat dijadikan contoh untuk pembelajaran sepanjang hayat. Karena di dalamnya mereka saling toleransi, tolong menolong dan suka dengan kedamaian.
Tidak bisa dipungkiri bahwa lingkungan masyarakat memberikan pengaruh yang besar terhadap proses belajar anak. Semua hal dan kejadian-kejadian yang ada di sekitar anak mempunyai pengaruh langsung terhadap pembentukan dan perkembangan anak. Lingkungan dapat memberikan pengaruh positif terhadap pembentukan dan perkembangan, tetapi sebaliknya lingkungan dapat pula memberikan pengaruh yang negatif.

Indrakusuma (1973: 32) menjelaskan bahwa yang dimaksud dengan pengaruh yang positif ialah apabila lingkungan itu memberikan kesempatan yang baik serta memberikan dorongan atau motivasi terhadap pembentukan dan perkembangan anak. Sedang yang dimaksud dengan pengaruh yang negatif ialah, apabila lingkungan itu tidak memberikan kesempatan yang baik dan bahkan menghambat terhadap proses pembelajaran dan pendidikan.

Contohnya kita belajar bahasa Inggris di suatu lingkungan dimana bahasa Inggris merupakan bahasa pergaulan sehari-hari. Di mana saja kita berada, kita harus menggunakan bahasa Inggris. Maka lingkungan yang demikian dikatakan memberikan pengaruh positif.

Misalnya lagi di sekolah kita memberikan pendidikan agama kepada anak. Tetapi di rumah, di dalam keluarga dari anak tersebut, juga di dalam keluarga dari tetangga-tetangganya tidak ada orang yang melaksanakan ibadah keagamaan. Bahkan dalam lingkungan itu sering terjadi, bahkan mengadakan hal-hal yang bertentangan dengan ajaran-ajaran agama yang diterima anak di sekolah. Maka dalam hal ini lingkungan itu memberikan pengaruh yang negatif.

Dengan demikian, lingkungan turut menentukan pada berhasil atau tidaknya pendidikan yang dilaksanakan. Kalau kita cermati bahwa lingkungan sebagai faktor pendukung proses belajar. Kalau di sekolah anak sudah dibiasakan mengerjakan hal-hal positif maka dilingkungan harus terus ditumbuhkan agar anak terbiasa mengerjakan hal positif tersebut.

Masyarakat sebagai sumber belajar hal ini ditegaskan oleh Ramayulis (2008: 139) beliau mengatakan sumber belajar mencakup dua aspek yaitu sumber pokok dan sumber tambahan. Sumber pokok ilmu pengetahuan adalah AlQur'an dan Hadits.

Pada masa awal pertumbuhan Islam, Nabi Muhammad Saw telah menjadikan Al-Qur'an sebagai sumber belajar pendidikan Agama Islam di samping Sunnah beliau sendiri (hadits). Kedudukan Al-Qur'an, sebagai sumber belajar yang paling utama dijelaskan dalam Al-Qur'an surah Al-Nahl: 64 yang artinya : “ Dan kami 
tidak menurunkan kepadamu Al-Kitab (AlQur'an) ini melainkan agar kamu dapat menjelaskan kepada mereka perselisihan itu dan menjadi petunjuk dan rahmat bagi kaum yang beriman". Al-Qur'an dan hadits merupakan sumber belajar yang paling utama untuk siapapun dan sampai kapanpun. Karena AlQur'an merupakan petunjuk manusia sepanjang hayat.

Sumber belajar tambahan salah satunya adalah manusia (orang, masyarakat). Misalnya guru, konselor, administratur pendidikan, tutor dan sebagainya. Untuk kepentingan yang lain dapat juga diambil dari luar sekolah seperti mubaliq, hakim agama, ulama, pemegang kebijakan dalam bidang pendidikan agama. Manusia sebagai sumber belajar terdapat dalam setiap jenis lembaga pendidikan (formal, non formal dan informal). Termasuk juga merupakan sumber belajar ialah situasi belajar atau lingkungan belajar.

Situasi dan lingkungan yang kondusif dapat dijadikan sebagai sumber belajar seperti gedung sekolah yang indah dan bersih, laboratorium keagamaan, taman yang indah dan menarik dan lain sebagainya. Di luar lingkungan sekolah ada pula sumber belajar lain seperti: masjid atau mushalla, majlis taklim dan berbagai jenis kegiatan keagamaan.

Lembaga-lembaga yang ada di dalam masyarakat seperti lembaga/organisasi sosial keagamaan (misal lembaga da'wah), Lembaga adat, Lembaga hukum, Lembaga bahasa, Lembaga profesi, yayasan-yayasan sosial dan perkumpulan-perkumpulan atas dasar suku dan wilayah dan sejenisnya tidak bisa diabaikan peranannya dalam pelengkap pendidikan anak.

Hasbullah (2001: 56) menjelaskan pendidikan ini mempunyai ciri-ciri sebagai berikut: diselenggarakan dengan sengaja di luar sekolah, peserta umumnya yang sudah tidak bersekolah atau drop out, tidak mengenal jenjang dan program pendidikan untuk jangka waktu pendek, peserta tidak perlu homogen, ada waktu belajar dan metode formal serta evaluasi yang bersifat sistematis. Isi pendidikan bersifat praktis dan khusus serta ketrampilan kerja sangat ditekankan sebagai jawaban terhadap kebutuhan meningkatkan taraf hidup.

Baharuddin dan Esa (2010: 118) menyatakan bahwa manusia selalu berusaha menyesuaikan diri dengan lingkungannya. Manusia cenderung mengorganisasikan tingkah laku dan pikirannya. Hal itu mengakibatkan adanya sejumlah struktur psikologis yang berbeda bentuknya pada setiap fase atau tingkatan perkembangan tingkah laku dan kegiatan berpikir manusia. Struktur ini disebut dengan struktur pikiran (intellectual scheme). Dengan demikian, pikiran harus memiliki suatu struktur yaitu skema yang berfungsi melakukan adaptasi dengan lingkungan dan menata lingkungan itu secara intelektual.

Secara sederhana skema dapat dipandang sebagai kumpulan konsep atau kategori yang digunakan individu ketika berinteraksi dengan lingkungannya. Skema ini senantiasa berkembang. Artinya ketika masih kecil seorang anak memiliki beberapa skema saja, tetapi setelah beranjak dewasa skemanya secara berangsur-angsur bertambah banyak, luas, beranekaragam dan komplek.

Perkembangan ini dimungkinkan oleh stimulus-stimulus yang dialaminya yang kemudian diorganisasikan dalam pikirannya. Piaget mengatakan skema orang dewasa berkembang mulai dari skema anak melalui proses adaptasi sampai pada penataan dan organisasi. Semakin mampu seseorang membedakan satu stimulus dengan stimulus lainnya makin banyak skema yang dimilikinya. Dengan demikian, skema adalah struktur kognitif yang selalu berkembang dan berubah. Proses yang menyebabkan adanya perubahan tersebut adalah asimilasi dan akomodasi.

Skema bisa diartikan sebagai naluri seorang anak untuk berinteraksi dan beradaptasi dengan lingkungannya. Semakin terbiasa berinteraksi dengan lingkungan maka semakin tumbuh terus skema tersebut. Oleh karena itu alangkah baiknya kalau lingkungan mendukung perkembangan dan pertumbuhan skema yang dimiliki oleh anak. Dengan cara menciptakan suasana pembelajaran yang baik dan kondusif.

Dengan demikian dapat dipahami bahwa dalam rangka memenuhi kebutuhan pendidikan, manusia memerlukan adanya lingkungan masyarakat sebagai lembaga pendidikan ketiga setelah keluarga dan sekolah yang mempunyai sifat dan fungsi yang berbeda serta keanekaragaman bentuk kehidupan sosial dan berjenis-jenis budayanya.

Lingkungan masyarakat adalah lingkungan pendidikan non formal yang memberikan pendidikan secara sengaja, terencana dan terarah kepada seluruh anggotanya yang pluralistik (majemuk) tetapi tidak dipersyaratkan berjenjang dan berkesinambungan serta dengan aturan-aturan yang lebih longgar untuk mengarahkan menjadi anggota masyarakat yang baik demi tercapainya kesejahteraan bersama.

Berdasarkan latar belakang diatas, maka rumusan masalah artikel ini yaitu Bagaimana proses belajar anak dalam lingkungan 
masyarakat? dan Sejauhmana peran masyarakat dalam membantu proses belajar anak?

\section{METODE}

Jenis penelitian yang digunakan dalam penulisan artikel ini adalah Library Research (penelitian kepustakaan), karena data yang diteliti berupa naskah-naskah, buku-buku yang bersumber dari khazanah kepustakaan.

Teknik pengumpulan data menggunakan metode dokumentasi. Teknik ini digunakan oleh penulis dalam rangka mengumpulkan data yang berkaitan dengan Peran Lingkungan Masyarakat sebagai Sumber Belajar.

Teknik analisis data menggunakan analisis isi (content analysis) dipergunakan untuk menarik kesimpulan yang sahih dari berbagai sumber atau referensi yang berhubungan dengan topik yang diangkat dalam penulisan artikel ini. Adapun langkah-langkahnya adalah dengan menseleksi teks yang akan ditulis, menyusun item-item yang spesifik dan melaksanakan penelitian.

\section{PEMBAHASAN}

\section{Proses Belajar Anak dalam Lingkungan Masyarakat}

Rasyid (2009: 64) menyatakan anak usia dini merupakan usia emas (the golden age) yang sangat potensial untuk melatih dan mengembangkan berbagai potensi multi kecerdasan yang dimiliki anak. Dalam Islam dinyatakan pula bahwa belajar di masa kecil bagai mengukir di atas batu, sedangkan belajar di usia senja bagai mengukir di atas air. Artinya usia dini adalah usia produktif untuk belajar, akan lebih mudah memahami ilmu apa pun ketika usia dini. Misalnya belajar berhitung, menulis, menggambar bahkan menghafal lebih efektif dilakukan di usia dini. Karena pada usia anak masih memiliki kekuatan pikiran yang tajam dan cerdas.

Hartati (2005:7-8) dalam 'Ulum (2014) menyatakan menurut NAEYC (National Assosiation Education for Young Children) anak usia dini adalah sekelompok individu yang berada pada rentang usia antara 0-8 tahun, pada usia tersebut manusia sedang berada dalam proses pertumbuhan dan perkembangan. Pengembangan potensi pada anak dapat dilakukan melalui pemberian stimulus yang tepat.

Pemberian stimulus bagi anak usia dini berbeda dengan pemberian bagi orang dewasa. Hal tersebut dikarenakan anak usia dini bukan merupakan bentuk mini dari orang dewasa., melainkan anak usia dini memiliki karakteristik yang berbeda dengan orang dewasa. Anak usia dini sangat aktif, dinamis, antusias, dan hampir selalu ingin tahu terhadap apa yang dilihat dan didengarnya.

'Ulum (2014: 519) menyebutkan potensi anak usia dini yang perlu dikembangkan mencakup seluruh aspek kemampuan dasar, yakni aspek fisik motorik, kognitif, sosio emosional, bahasa, seni serta nilai agama dan moral. Berbagai upaya perlu dilakukan untuk mengembangkan aspek-aspek perkembangan anak tersebut. Termasuk penyediaan media dan sumber belajar yang menunjang pengembangan berbagai aspek perkembangan anak. Sedangkan lingkungan yang ada di sekitar anak-anak merupakan salah satu sumber belajar yang dapat dioptimalkan untuk pencapaian proses hasil pendidikan yang berkualitas. Jumlah sumber belajar yang tersedia di lingkungan ini tidaklah terbatas, sekalipun pada umumnya tidak dirancang secara sengaja untuk kepentingan pendidikan.

Ramayulis (2008: 142) menyebut bahwa kita dapat membedakan tiga lingkungan sebagai sumber belajar yaitu: Pertama, Lingkungan Terbuka, yang dimaksud dengan lingkungan terbuka ialah alam itu sendiri tanpa kehadiran "manusia". Anak dapat mengenal dan menikmati alam sehingga ia dapat melihat, merasakan dan menikmati keagungan Tuhan. Anak dapat menemukan sesuatu yang baru dari kehidupan makhluk Tuhan untuk bersyukur kepada-Nya.

Saat ini mulai banyak lembaga pendidikan baik formal maupun non formal yang menggunakan metode belajar dengan lingkungan. Misalnya adanya kegiatan out bond, kegiatan ini secara langsung mengenalkan anak dengan lingkungannya. Dengan begitu anak akan mendapatkan pengetahuan dan informasi yang beragam. Misalnya bagaimana merawat lingkungan, menyayangi binatang dan lain-lain. Sehingga kebiasaan yang baik seperti ini akan membentuk karakter mereka. Selain itu ada lembaga pendidikan “ Sekolah Alam”. Pada lembaga ini kegiatan pembelajaran yang lebih dominan dilakukan di luar kelas, dengan tujuan dapat menerima informasi sekaligus menikmati keindahan alam.

Kedua, Lingkungan Sejarah atau Peninggalan Sejarah. Yang dimaksud lingkungan sejarah ialah berupa tempat-tempat bersejarah maupun peninggalan sejarah yang telah tersusun seperti museum. Dari alam lingkungan ini dapat memperoleh iktibar atau pengajaran sehingga peserta didik memperoleh nilai-nilai baru bagi dirinya.

Dalam pengenalan lingkungan sejarah ini biasanya diadakan kegiatan study tour yaitu 
belajar sekaligus berwisata. Misalnya kegiatan mengunjungi candi, museum, keraton dan lainlain. Pendidikan seperti ini secara tidak langsung juga bisa meningkatkan nilai religius siswa. Yakni memahami tanda kebesaran Allah melalui ciptaan-Nya.

Ketiga, Alam Lingkungan Manusia atau Lingkungan Masyarakat. Lingkungan masyarakat mulai yang terkecil ialah keluarga hingga lingkungan pendidikan. Pengaruh masyarakat terhadap anak sangat besar. Terutama pengaruh lingkungan keluarga.

Pengaruh yang beraneka ragam tidak selalu menguntungkan anak. Dengan demikian penggunaannya sebagai sumber belajar harus selektif. Untuk itu masyarakat hendaknya menciptakan lingkungan yang baik dengan melakukan kebiasaan-kebiasaan yang baik sehingga dapat menjadi sumber belajar anak. Karena usia anak adalah proses belajar mereka yang dominan ialah meniru kebiasaan orangorang yang mereka lihat. Dengan melihat kebiasaan yang baik maka harapannya ialah anak melakukan hal-hal yang baik pula.

Syah (2003) dalam Baharuddin (2010: 26-

27) menjelaskan bahwa faktor-faktor eksternal yang memengaruhi belajar dapat digolongkan menjadi dua faktor yaitu faktor lingkungan sosial dan faktor lingkungan nonsosial. Yang termasuk Lingkungan Sosial diantaranya ialah: pertama, Lingkungan Sosial Sekolah. Seperti guru, administrasi, dan teman-teman sekelas dapat memengaruhi proses belajar seorang siswa.

Hubungan yang harmonis antara ketiganya dapat menjadi motivasi bagi siswa untuk belajar lebih baik di sekolah. Perilaku yang simpatik dan dapat menjadi teladan seorang guru atau administrasi dapat menjadi pendorong bagi siswa untuk belajar. Lingkungan belajar di Sekolah yang kondusif dapat menumbuhkan semangat siswa untuk belajar. Selain itu kondisi kelas yang bersih dan nyaman juga harus selalu dijaga. Karena suasana yang demikian dapat menunjang kenyamanan dalam belajar. Bisa dibayangkan kalau kondisi ruang kelas yang kumuh dan kotor, masuk di dalamnya saja merasa tidak nyaman apalagi konsentrasi untuk belajar.

Kedua, Lingkungan Sosial Masyarakat. Kondisi lingkungan masyarakat tempat tinggal siswa akan memengaruhi belajar siswa. Lingkungan siswa yang kumuh, banyak pengangguran dan anak telantar juga dapat memengaruhi aktivitas belajar siswa, paling tidak siswa kesulitan ketika memerlukan teman belajar, diskusi, atau meminjam alat-alat belajar yang kebetulan belum dimilikinya.
Lingkungan masyarakat disini bisa dilihat dari berbagai aspek. Yaitu hubungan antar orang perorang dalam masyarakat atau juga kondisi lingkungan itu sendiri. Ketika kondisi lingkungan bersih dan asri setidaknya mendukung untuk kegiatan belajar, begitu pula sebaliknya. Masyarakat yang ramah, penyantun serta memiliki hubungan yang harmonis, tentunya dapat dijadikan teman untuk belajar atau bahkan kita jadikan sumber belajar.

Ketiga, Lingkungan Sosial Keluarga. Lingkungan ini sangat memengaruhi kegiatan belajar. Ketegangan keluarga, sifat-sifat orang tua, demografi keluarga (letak rumah), pengelolaan keluarga, semuanya dapat memberi dampak terhadap aktivitas belajar siswa. Hubungan antara anggota keluarga, orang tua, anak, kakak, atau adik yang harmonis akan membantu siswa melakukan aktivitas belajar dengan baik.

Keluarga merupakan tempat anak mengenyam pendidikan pertama kali. Oleh karenanya dalam Islam dikatakan bahwa ibu adalah madrasah pertama untuk anak-anaknya. Keluarga menjadi peletak dasar dan karakter anak. Ketika sejak kecil dibiasakan pada hal-hal yang positif maka akan tertanam kuat sampai mereka dewasa. Pendidikan karakter dalam keluarga itulah yang dapat menjaga serta melindungi mereka pada lingkungan sekitar yang kurang mendukung untuk proses belajarnya.

Kehidupan keluarga itu ibarat sekolah terbuka dengan jurusan atau materi pendidikan yang tidak terhingga. Barang siapa sanggup mengelolanya dengan baik, maka Allah Swt akan menganugerahkannya keberkahan. Rasyid (2017: 85-86) menyatakan kehidupan keluarga yang terdiri atas suami istri dan anak-anak akan menjadi potret kesempurnaan. Didalamnya Allah SWT tidak saja memberikan keteduhan berupa cahaya ilmu, namun juga ketenteraman hati sebagai buah dari amanah atau tanggung jawab yang telah dijaga.

Lingkungan nonsosial terdiri dari: pertama, Lingkungan Alamiah. Seperti kondisi udara yang segar, tidak panas dan tidak dingin, sinar yang tidak terlalu silau atau kuat, atau tidak terlalu lemah/gelap, suasana yang sejuk dan tenang. Lingkungan alamiah tersebut merupakan faktor-faktor yang dapat memengaruhi aktivitas belajar siswa. Sebaliknya bila kondisi lingkungan alam tidak mendukung, proses belajar siswa akan terhambat.

Kalau kita lihat bahwa lingkungan alamiah ini nampak sepele namun sangat penting sekali diperhatikan ketika ingin memperoleh hasil belajar yang efektif. Kedua, Faktor Instrumental. Yaitu perangkat belajar yang dapat 
digolongkan dua macam. Pertama hardware seperti gedung sekolah, alat-alat belajar, fasilitas belajar, lapangan olahraga dan lain sebagainya. Kedua, software seperti kurikulum sekolah, peraturan-peraturan sekolah, buku panduan, silabi dan lain sebagainya.

Kembali pada pembahasan awal, dalam hal ini Indrakusuma (1973: 84)) mengatakan bahwa faktor lingkungan disebut juga faktor ajar. Dengan demikian lingkungan dapat berupa benda-benda, orang-orang, keadaan-keadaan dan peristiwa-peristiwa yang ada disekitar anak yang bisa memberikan pengaruh pada perkembangannya. Baik secara langsung atau tidak langsung, baik secara disengaja ataupun tidak disengaja. Disamping lingkungan itu memberikan pengaruh dan dorongan, lingkungan juga merupakan arena yang memberikan kesempatan kepada kemungkinan-kemungkinan (pembawaan) yang ada pada seorang anak untuk berkembang.

Pada sumber lain dikatakan bahwa faktor yang mempengaruhi belajar ialah faktor pembawaan (nativisme) dan lingkungan (empirisme). Dua faktor ini saling berkaitan satu dengan yang lain serta tidak dapat dipisahkan. Ketika faktor pembawaannya baik kemudian pengaruh lingkungan yang baik maka potensi anak dapat berkembang dengan baik pula.

Bagaimanapun baik pembawaan seorang anak, tanpa adanya kesempatan dan pendidikan, maka pembawaan yang baik itu akan tetap hanya merupakan pembawaan saja, dan tidak berkembang. Seperti halnya anak-anak yang hidup di desa. Biarpun ia setiap kali menjadi juara terpandai di dalam kelasnya, karena ia tetap tinggal di desa, di mana desa (lingkungan) itu tidak memberikan kesempatan baginya untuk mengembangkan pembawaannya, maka pembawaan yang baik itu tetap hanya merupakan pembawaan saja dan tidak pernah berkembang. Sangat berpengaruh sekali faktor lingkungan dalam mengawal proses belajar anak. Pembawaan yang baik tanpa adanya peran lingkungan yang baik maka pembawaan yang potensial tersebut tidak dapat dikembangkan.

Sebaliknya, meskipun pembawaan itu kurang baik, tetapi lingkungan memberikan dorongan yang cukup dan kesempatan yang leluasa, maka pembawaan yang kurang baik itu bisa berkembang mencapai tingkat yang maksimal. Seperti halnya dengan anak-anak yang tinggal di kota-kota. Biarpun sebagian anak itu sebenarnya mempunyai pembawaan yang kurang baik misalnya, tetapi lingkungan selalu memberikan dorongan dan kesempatan maka dapat dicapai pula perkembangan yang maksimal.
Beberapa pendapat tokoh lebih menekankan pentingnya peran lingkungan dari pada pembawaan. Bahkan sebagian dari mereka tidak mengakui adanya pembawaan dalam perkembangan.

Pendapat atau teori yang demikian diantaranya ialah yang dikemukakan oleh John Locke dengan Tabularasa-teori. Arti yang sebenarnya dari kata Tabularasa ialah meja dari lilin untuk tempat menulis.

Menurut teori Tabularasa, bahwa anak yang dilahirkan itu keadaannya masih bersih, tidak mengandung apa-apa, tidak ada pembawaan apa-apa. Anak lahir diumpamakan seperti sehelai kertas yang putih bersih masih kosong. Akan ditulisi apa kertas itu dan akan digambari yang bagaimana kertas itu, terserah kepada si pendidik. Si pendidik bisa berbuat apa saja yang ia ingini di atas kertas yang masih bersih itu. Si pendidik bisa menjadikan anak didik itu apa saja. Dengan demikian, di sini dapat dikatakan, bahwa pendidikan itu maha kuasa.

Selaras dengan hal itu maka agama Islam menyatakan bahwa anak terlahir dalam keadaan fitrah atau suci. Anak yang baru lahir masih putih, bersih belum mempunyai dosa. Fitrah itu bisa diartikan juga belum terpengaruh dengan hal-hal yang negatif. Maka dari itu peran keluarga dan lingkunganlah yang dapat memberikan pengaruh-pengaruh positif kepada si anak, sehingga menjadi anak yang baik dan bermanfaat bagi lingkungannya.

Tokoh lain yang tidak mengakui adanya pembawaan seperti Emanuel Kant. Ia menyatakan bahwa manusia (budaya) tidak lain adalah hasil dari pendidikan, dengan demikian berarti, bahwa pendidikan sanggup membuat manusia yang bagaimana saja.

Pendapat Emanuel Kant tersebut senada dengan teori belajar Konstruktivisme. Menurut teori ini pengetahuan dan proses belajar pada dasarnya adalah berakar dari interpretasi unik seseorang terhadap dunianya atau lingkungan disekitarnya. Pandangan ini lebih menekankan upaya penataan pembelajaran setiap individu dengan karakteristiknya terhadap interpretasi pengalaman dan lingkungannya.

Sutiah (1997 : 11) memaparkan selain teori Konstruktivisme, teori Behaviorisme menganggap segala kejadian di lingkungan sekitar sangat mempengaruhi seseorang dan akan memberikan pengalaman tertentu dalam dirinya. Belajar menurut teori ini adalah perubahan tingkah laku yang terjadi berdasarkan paradigma S-R (stimulus-respon), yaitu suatu proses yang memberikan respon tertentu terhadap yang datang dari luar diri individu. Dengan demikian belajar adalah perubahan tingkah laku. Seorang 
anak dianggap telah belajar bila ia mampu menunjukkan perubahan tingkah laku dari stimulus yang diterimanya.

\section{Peran Masyarakat dalam Membantu Proses Belajar Anak}

Suparta dan Aly (1998: 24) menyebut bahwa masyarakat apabila dilihat dari konsep sosiologi adalah sekumpulan manusia yang bertempat tinggal dalam suatu kawasan dan saling berinteraksi. Bila dilihat dari konsep pendidikan, masyarakat adalah sekumpulan orang dengan berbagai ragam kualitas diri mulai dari yang tidak berpendidikan sampai pada yang berpendidikan tinggi. Ia adalah laboratorium besar tempat para anggotanya mengamalkan semua keterampilan yang dimilikinya.

Mereka saling belajar memahami karakter masing-masing demi kebersamaan dan persatuan. Masyarakat satu dengan yang lain mempunyai adat istiadat yang berbeda-beda sehingga hal tersebut dapat memperkaya khasanah kebudayaan setempat. Kaitan masyarakat dan pendidikan dapat ditinjau dari tiga segi, yakni sebagai berikut: pertama, Masyarakat sebagai penyelenggara pendidikan. kedua, lembaga-lembaga kemasyarakatan dan atau kelompok sosial dalam masyarakat, baik langsung maupun tidak, ikut mempunyai peran dan fungsi edukatif. ketiga, dalam masyarakat tersedia berbagai sumber belajar.

Naya (tt:76). menyatakan dilihat dari lingkungan pendidikan, masyarakat disebut lingkungan pendidikan non formal yang memberikan pendidikan secara sengaja dan berencana kepada seluruh anggotanya, tetapi tidak sistematis. Secara fungsional masyarakat menerima semua anggotanya yang pluralistik (majemuk) dan mengarahkan menjadi anggota masyarakat yang baik untuk tercapai kesejahteraan sosial yaitu kesejahteraan mental spiritual dan fisik atau kesejahteraan lahir dan batin.

Kemajemukan dalam masyarakat merupakan sumber pengetahuan. Mulai dari karakternya, adat istiadat, kebudayaan, serta kebiasaan dan kegiatan yang bersifat positif. Kalau kita lihat mereka ada yang mempunyai kegiatan rutin misalnya mingguan, bulanan atau bahkan selapanan. Semua itu tidak lain ialah untuk mengembangkan potensi individu masyarakat tersebut.

Kasim dkk (1995: 276) memaparkan bahwa kurikulum tidak boleh lepas dari masyarakat. Pemanfaatan fakta dan realitas sosial yang terdapat dalam masyarakat sebagai sumber belajar dapat dilakukan dengan dua cara, yaitu dengan cara membawa sumber dari masyarakat (lingkungan) ke dalam kelas dan dengan cara membawa siswa (kelas) ke dalam lingkungan. Tentunya masing-masing cara tersebut dapat dilakukan dengan pendekatan , metode, teknik, dan bahan bantu tertentu sesuai dengan tujuan pengajaran. Tujuan pendidikan salah satunya ialah untuk menyiapkan peserta didik agar dapat menjawab tantangan yang ada dalam masyarakat. Oleh karenanya alangkah baiknya jika kurikulum dirancang sesuai dengan kebutuhan masyarakat tersebut.

Kalau di lembaga pendidikan pendidiknya adalah guru, maka kalau di masyarakat yang menjadi pendidiknya adalah orang dewasa yang bertanggungjawab terhadap pendewasaan anggotanya melalui sosialisasi lanjutan yang diletakkan dasar-dasar oleh keluarga dan juga sekolah sebelum mereka masuk ke dalam masyarakat. Masing-masing anggotanya dengan penuh kesadaran dan tanggung jawab baik secara sendiri-sendiri atau secara bersama melalui institusi atau lembaga yang dipimpinnya.

'Ulum (2014: 520) menjelaskan lingkungan sekitar dikatakan sebagai sumber belajar karena: pertama, menyediakan berbagai hal yang dapat dipelajari anak. Jumlah sumber belajar yang tersedia di lingkungan ini tidaklah terbatas, sekalipun pada umumnya tidak dirancang secara sengaja untuk kepentingan pendidikan.

Sumber belajar lingkungan ini akan semakin memperkaya wawasan dan pengetahuan anak, karena mereka belajar tidak terbatas oleh empat dinding kelas. selain itu kebenarannya lebih akurat, sebab anak mengalami langsung dan dapat mengoptimalkan potensi panca inderanya untuk berkomunikasi dengan lingkungan tersebut. Kalau di kelas lebih banyak belajar teori pengetahuan sedangkan dalam masyarakat adalah tempat untuk mengaplikasikan teori-teori.

Teori dan praktik harus berjalan beriringan. Teori tanpa praktik terasa kurang sempurna, begitu juga apa yang akan dipraktikkan kalau tidak mempelajari teorinya dengan sungguh-sungguh. Kegiatan belajar dimungkinkan akan lebih menarik bagi anak sebab lingkungan menyediakan sumber belajar yang sangat beragam dan banyak pilihan. Kegemaran belajar sejak usia dini merupakan modal dasar yang sangat diperlukan dalam rangka penyiapan masyarakat belajar (learning societes). Dan sumber daya manusia di masa mendatang.

Kedua, pemanfaatan lingkungan menumbuhkan aktivitas belajar anak (learning activities), yang lebih meningkat. Penggunaan cara atau metode yang bervariasi merupakan 
tuntutan dan kebutuhan yang harus dipenuhi dalam pendidikan untuk anak usia dini. Begitu banyaknya nilai dan manfaat yang dapat diraih dari lingkungan sebagai sumber belajar dalam pendidikan anak usia dini. Bahkan hampir semua tema kegiatan dapat dipelajari dari lingkungan. Namun demikian diperlukan adanya kreativitas dan jia inovatif dari para guru untuk dapat memanfaatkan lingkungan sebagai sumber belajar.

Menurut hemat penulis lingkungan dikatakan sebagai sumber belajar sekaligus metode pembelajaran. Metode pembelajaran dengan melibatkan lingkungan sebagai sumber ajarnya. Menggunakan metode yang aktif dan kreatif sangat penting sekali dalam pembelajaran, yaitu guna untuk meningkatkan semangat belajar siswa. Oleh karena nya ada yang mengatakan kalau metode itu lebih diutamakan dari pada materi. Artinya dengan metode yang bagus dan bervariasi itu membuat anak semangat untuk belajar. Lingkungan merupakan sumber belajar yang kaya dan menarik untuk anak-anak. Lingkungan manapun bisa menjadi tempat yang menyenangkan bagi anak-anak.

Rasyid (2017: 148-149) menyatakan pentingnya belajar pada lingkungan masyarakat. Pendidikan sosial-kemasyarakatan adalah salah satu poin penting bagi anak dalam mengamalkan ajaran-ajaran sosial yang tercantum dalam AlQur'an, sebagaimana yang telah dicontohkan oleh Rasulullah Saw. Karena itu, kalau kita kaji kembali isi Al-Qur'an, maka kita akan menemukan bahwa kalam Allah Swt. itu tidak hanya berbicara tentang hukum-hukum ibadah mahdhah saja, melainkan juga mencakup aktifitas-aktifitas sosial sebagai bagian dari hablun minannas.

Dalam masyarakat anak belajar berinteraksi dan bersosialisasi dengan orang lain. Hal ini harus dibiasakan sejak dini pada anak. Dengan berinteraksi dan bersosialisasi dengan orang lain maka akan dapat menumbuhkan kecerdasan sosial mereka. Dengan demikian mereka tidak menjadi seseorang yang individual semata, melainkan menjadi pribadi yang peka terhadap lingkungannya.

Pada masyarakat anak akan banyak belajar nilai-nilai positif yang mana bermanfaat untuk perkembangan kepribadiannya. Belajar memahami setiap individu dalam masyarakat. Karena setiap kelompok masyarakat tidak sama dengan kelompok masyarakat lainnya. Maka tentu dibutuhkan cara bergaul yang cerdas dan penuh kelembutan sehingga dengan mudah diterima oleh orang lain. Cara-cara bergaul itulah yang diteladankan dengan sempurna oleh Rasulullah SAW.
Dengan menyatu pada masyarakat maka secara tidak langsung anak belajar bagaimana cara bergaul yang baik. Bergaul dengan penuh kelembutan, sopan santun, dan dengan etika yang baik maka akan mudah diterima masyarakat.

Dengan demikian, belajar tentang pendidikan sosial dan kemasyarakatan akan mengantarkan anak menjadi pribadi-pribadi yang arif. Anak akan memahami karakter masingmasing individu yang memiliki latar belakang sosial yang beragam. Dengan memahami seperti itu, anak akan melihat keagungan Allah Swt. sekaligus menumbuhkan rasa syukur kepada-Nya yang telah menciptakan manusia dengan kultursosial yang beragam.

Disatu sisi Indrakusuma (1973) mengatakan bahwa dalam masyarakat, di samping terdapat hal-hal yang memberikan pengaruh positif pada pendidikan dan perkembangan anak, juga banyak hal-hal yang memberikan pengaruh negatif. Sehubungan dengan pengaruh-pengaruh yang bersifat positif dan pengaruh-pengaruh yang bersifat negatif dari masyarakat ini, maka aktifitas pribadi memainkan peranan yang penting. Ke mana aktivitas pribadi itu digerakkan, maka ke situ pula arah perkembangan dari seseorang.

Sebagai subjek belajar maka anak seyogyanya diarahkan pada lingkungan yang bisa mendukung proses belajar mereka. Karena lingkungan sangat mempengaruhi perkembangan anak pada tahap selanjutnya. Disini perlunya dengan cermat memilih lingkungan belajar yang tepat sebagai sumber belajar. Sebab pemilihan lingkungan belajar yang kurang tepat bisa menghambat proses belajar si anak. Maka dari itu sebagai orang tua harus selalu mendampingi dan mengarahkan anak pada setiap proses perkembangannya.

Lebih lanjut Indrakusuma (1973) menegaskan bahwa disamping pengaruh positif dan negatif itu, masih ada juga hal-hal dalam masyarakat yang memberi pengaruh kepada perkembangan dan pendidikan anak. Seperti halnya situasi politik, situasi ekonomi, situasi sosial dan juga situasi keamanan. Situasi politik yang menyebabkan negara dalam keadaan perang atau timbulnya banyak pemberontakanpemberontakan sering mengakibatkan kegagalan-kegagalan, hambatan-hambatan dan kekecewaan-kekecewaan bagi anak yang sedang membutuhkan pendidikan.

Situasi ekonomi kacau, yang menyebabkan kacaunya perekonomian masyarakat, masyarakat menjadi tidak tenang, akan berpengaruh pula pada dunia pendidikan dan pendidikan anak-anak. Situasi sosial dalam masyarakat tidak tertib, banyak terjadi 
penyelewengan-penyelewengan, manipulasi dan korupsi akan berpengaruh besar terhadap perkembangan jiwa anak ke arah hal-hal yang negatif pula.

Untuk itu menjadi tanggung jawab kita sebagai orang untuk menciptakan suasana yang kondusif dan stabil. Misalnya dimulai pada lingkungan masyarakat yang terkecil yakni keluarga. Bagaimana si Ayah menciptakan suasana belajar di dalam rumah, membiasakan nilai positif kepada anak, serta yang terpenting ialah tidak ada konflik dalam keluarga. Situasi yang seperti ini yang diharapkan untuk proses belajar si anak. Bagaimanapun konflik sekecil apapun di dalam keluarga akan dapat mengganggu kegiatan belajar anak. Kemudian lebih luas lagi menciptakan suasana kondusif pada lingkungan masyarakat, lingkungan daerah, lingkungan pemerintahan dan lain sebagainya. Kalau sudah demikian semua lingkungan bersinergi menciptakan suasana pembelajaran yang kondusif maka tujuan belajar akan tercapai.

Lingkungan sekitar yang kondusif akan menambah keseimbangan dalam kegiatan belajar si anak. Artinya belajar tidak hanya terjadi di ruangan kelas saja namun juga diluar ruangan kelas dalam hal ini lingkungan sebagai sumber belajar yang sangat berpengaruh terhadap perkembangan fisik, keterampilan sosial, dan budaya, perkembangan emosional serta intelektual.

Belajar pada lingkungan akan sangat menambah wawasan pengetahuan anak. Karena di dalamnya tidak hanya belajar pengetahuan secara kognitif saja, melainkan secara keseluruhan. Pada lingkungan anak dapat belajar sikap (afektif), bagaimana menumbuhkan toleransi, saling menghargai, tolong menolong dan lain sebagainya. Oleh karena itu belajar yang demikian akan menumbuhkan sikap sosial terhadap masyarakat. Selain itu belajar pada lingkungan akan menumbuhkan keterampilan pada anak (psikomotorik). Misalnya dengan kegiatan praktik dan mengamati, maka anak akan mengetahui dan mengalami secara langsung.

Dengan demikian, belajar tentang pendidikan sosial dan kemasyarakatan akan mengantarkan anak menjadi pribadi-pribadi yang arif. Anak akan memahami beragam pengetahuan dan memahami karakter masingmasing individu yang memiliki latar belakang sosial yang beragam. Dengan memahami seperti itu akan mengetahui keagungan Allah Swt. sekaligus akan menumbuhkan rasa syukur kepada-Nya yang telah menciptakan manusia dengan kultur-sosial yang beragam.

Mempelajari aspek-aspek sosial, pada gilirannya akan mengantarkan anak menjadi manusia berkualitas dan berpotensi untuk bermanfaat kepada sesama. Dalam kontek pendidikan Islam, jelas mempelajari semua itu merupakan suatu kewajiban. Siswa atau murid akan memiliki pemahaman yang utuh mengenai cara hidup bertetangga dan berperilaku yang baik dengan sesama.

Tentu saja, realisasi pendidikan sosial itu harus berlandaskan pada Al-Qur'an dan hadits. Kajian yang mendalam tentang masyarakat dalam pandangan Al-Qur'an serta hadits akan menghasilkan output yang memiliki kepedulian, perhatian dan dedikasi terhadap lingkungan sosialnya. Dengan memahami konsep masyarakat, maka akan muncul generasigenerasi yang siap menjadi agen bagi kemanfaatan sosial. Dengan bersosialisasi dengan masyarakat harapannya adalah anak mempunyai jiwa sosial dan rasa empati yang tinggi. Lalu kemudian menjadi pribadi yang peka terhadap lingkungannya.

Bagaimanapun lingkungan sekitar adalah lingkungan tempat tinggal anak. Mereka merupakan bagian dari saudara dan keluarga kita. Kapanpun mereka meminta tolong maka sudah menjadi kewajiban kita untuk menolongnya. Semoga ulasan yang sederhana ini ada guna dan manfaatnya. Akhirnya semoga anak-anak kita kelak menjadi pribadi yang bermanfaat dunia dan akhirat, aamiin. Wallahua'lam

\section{Penutup}

Upaya pemanfaatan lingkungan sekitar sebagai sumber belajar anak harus diupayakan seoptimal mungkin. Karena pada dasarnya lingkungan sekitar menyediakan berbagai pengalaman belajar yang bermanfaat bagi anak. Belajar dengan cara menyatu pada lingkungan akan memberikan pengalaman nyata bagi anak. Mereka tidak saja belajar teori melainkan mengamati dan merasakan langsung. Para ahli mengatakan juga, bahwa lingkungan sekitar sebagai sumber belajar sangat berpengaruh terhadap perkembangan fisik, keterampilan sosial, dan budaya, perkembangan emosional dan intelektual si anak. Dengan demikian tiga ranah aspek pembelajaran dapat dikembangkan yaitu kognitif, afektif, maupun psikomotoriknya. Belajar dengan cara bersosialisasi dan berkomunikasi secara langsung dengan masyarakat akan menumbuhkan sikap kepedulian dan jiwa sosial anak. Bagaimanapun juga jiwa sosial harus terus dikembangkan sehingga mereka menjadi pribadi yang peka terhadap lingkungannya. Pada lingkungan tersedia berbagai hal yang dapat dipelajari dan diamati oleh anak. Jumlah sumber belajar yang 
ada di dalamnya pun tidak terbatas. Sumber belajar lingkungan ini akan menambah wawasan dan pengetahuan anak karena mereka mengalami secara langsung dan dapat mengoptimalkan potensi panca inderanya untuk berkomunikasi dengan lingkungan tersebut. Untuk itu sebagai orang tua hendaknya selalu mengawal setiap perkembangan belajar anak, supaya mereka dapat mengembangkan bakat dan potensinya dengan optimal.

\section{DAFTAR PUSTAKA}

Abdurrahman, H dan Soerjono. 1999. Metode Penelitian Deskriptif. Jakarta: PT. Rineka Cipta.

Barnadib, Sutari Imam. 1971. Pengantar Ilmu Pendidikan. Yogyakarta: FIP-IKIP Yogyakarta.

Baharuddin dan Nur Wahyuni, Esa. 2010. Teori Belajar dan Pembelajaran. Jogjakarta: ArRuzz Media.

Dewantara, Ki Hadjar. 2013. KI HADJAR DEWANTARA Bagian Pertama: Pendidikan. Yogyakarta: Penerbit Universitas Sarjanawiyata Taman Siswa (UST-Press) bekerjasama dengan Majelis Luhur Persatuan Taman Siswa.

Hasan Kasim dkk. 1985. "Pemanfaatan Lingkungan Sebagai Sumber Belajar Ilmu Pengetahuan Sosial Pada Sekolah Menengah Umum Tingkat Pertama di Kotamadya Banda Aceh". Jurnal Ilmu Pendidikan 2 (3).
Hasbullah. 2001. Dasar-dasar Ilmu Pendidikan. Jakarta: PT. Raja Grafindo Persada.

Indrakusuma, Amir Daien. 1973. Pengantar Ilmu Pendidikan. Malang: Fakultas Ilmu Pendidikan.

M. Suparta dan Noer Aly, Herri. 1998. Metodologi Pengajaran Agama Islam. Jakarta: Rineka Cipta.

Purwanto, M. Ngalim. 1994. Ilmu Pendidikan Teoritis dan Praktis. Bandung: Remaja Rosda Karya.

Ramayulis. 2008. Metodologi Pendidikan Agama Islam. Jakarta: Kalam Mulia.

Rasyid dkk, Harun. 2012. Asesmen Perkembangan Anak Usia Dini. Yogyakarta: Gama Media.

Rasyid, M.Ainur. 2017. Hadits-Hadits Tarbawi. Jogjakarta: Diva Press.

Suti'ah. 1997. Buku Ajar Perencanaan Sistem Pengajaran. Malang: STAIN.

Syam, Mohammad Noor. 1984. Filsafat Pendidikan dan Dasar Filsafat pendidikan Pancasila. Surabaya: Usaha Nasional.

'Ulum, Irfatul. 2014. Pemanfaatan Lingkungan Sebagai Sumber Belajar Anak. Jurnal Pendidikan Anak 3 (2), hlm: 518-523. 